\title{
Branding Corporate Social Responsibility: A Case Study on Public-Listed Telecommunication Companies in Malaysia
}

\author{
JAMILAH AHMAD \\ Universiti Sains Malaysia, Malaysia
}

Corporate social responsibility (CSR) is a pillar for any organization to portray the positive reputation of the organization to the public. The image and commitment of CSR initiatives reflect the corporate brand of the organization. This study aims to have a better understanding of brand and CSR from the role of public relations practitioner involving two telecommunication companies namely Maxis Berhad and Axiata group which are public-listed companies in Malaysia. A qualitative indepth interview was carried out with both public relations senior practitioners. Findings indicated that public relations practitioners from both telecommunication companies have a common understanding of branding CSR within the respective company. Despite, the differences in the basis of branding CSR, it is also found that CSR plays an important role to strengthen the corporate brand.

Keywords: Corporate social responsibility, corporate brand, public relations, Axiata group, Maxis Berhad, public-listed companies

Corporate social responsibility (CSR) is the term most often used to describe an evolving dialogue that seeks to expand the role of the organization beyond the economic frame to include social and environmental aspects of the community. Many studies argue that companies benefit from adopting CSR either in the monetary form or good reputation. There are numerous reasons why organizations adopt CSR. Davis (2014) for instance argues that the long run self-interest is one of the most prevalent reasons to practice CSR. Jamilah and Suriati (2017) state that CSR includes the responsibilities of corporations to the communities and societies within which they are based and operate. Specifically, it involves a business or corporation identifying its stakeholders and incorporating their needs and values in its day to day decision-making process and practices (Jamilah \& Suriati, 2017). Corporate Social Responsibility (CSR) considers; the current and future impact of business operations, purchasing, and the sale of products and services on; the environment, employees, local community and society in general (UNICEF, 2014). Corporate Social Responsibility is a set of voluntary actions a business takes over and above compliance with the law. It includes, but is not limited to corporate governance and philanthropy (Bouluta \& Pitalis, 2014).

CSR itself has evolved throughout the world in the past decade, and this evolvement is also reflected within Malaysia with the Government active participation to encourage companies to engage with the community either through social or environmental aspects. Malaysia is also actively promoting corporate social reporting, perhaps to be in line with

Correspondence to: Jamilah Ahmad, School of Communication, Universiti Sains Malaysia, 11800 USM Penang, Malaysia 
recent developments in which Bursa Malaysia made it mandatory for listed companies to disclose a CSR statement. Such a movement indicates that Malaysia, through appropriate agencies, is seriously promoting CSR (Azlan et al., 2013). This is one of the main reason why CSR has become an extremely important economic, social and political issues for both developed and developing countries at all levels (Carroll, 1999; Matten \& Crane, 2005; Jamilah \& Suriati, 2017).

CSR in Malaysia was formally instituted by several companies in the 1970 s. At the turn of the century, it expanded along lines similar to the CSR movements in other Asian countries (Ismail, Alias, \& Rasdi, 2015). Abdul Rashid and Ibrahim (2010) found that Malaysian executives and managers were found to have positive attitudes towards CSR. This growth is attributed to increasing government and regulatory involvement, heightened awareness of sustainability concerns amongst local media and civil society, and the private sector is becoming more engaged with corporate responsibility (Smith et al., 2010).

Illustration of how CSR is integrated into credible brand management, assuming that business needs to 'walk the talk' as well as 'chalk the walk' in other words communicate their CSR conduct. The challenges lie in communicating corporate values expressed in strategies and everyday procedures to stakeholders with a variety of interests and expectations (Whitehouse, 2006).

\section{Conceptualizing Corporate Social Responsibility}

With many researchers conducted on CSR, it has calculated to different definitions and conceptualizations of CSR, the various views articulate contrasting arguments as to the role of business in society, and to what or whom companies are responsible. In 1984, Milton Friedman presented an economic view of corporate responsibility. 'The Social Responsibility of Business is to increase its Profits' he argues that: 'If there are 'social responsibilities,' they are the social responsibilities of individuals, not of business' (Friedman, 1984). As the title of the article implies, Friedman argues that corporations solely have one responsibility, which is to maximize their profits and thereby address the interests of the shareholders. Friedman personifies the classical economic argument, conceptualizing CSR from an economic point of view.

Additionally, it has been argued that CSR drives attention away from the primary purpose of business and that company already has enough power within their primary field, meaning that engaging in CSR would only be an attempt to gain a powerful role in a competing field. (Caroll \& Shabana, 2010). Since CSR behaviors are charitable and discretionary, the likelihood that a company will engage CSR will also depend on the characteristics of the business and management. According to Richardson, Welker and R. Hutchinson (2013), a company may decide to take a proactive attitude on an ethical issue in the absence of specific pressures for that company to act, more specifically it is voluntary. On the other hand, it is possible for the company with publicly known CSR related issues to take no action with regards to these problems.

\section{Stakeholder Theory}

Modern theories on CSR often take a stakeholder perspective, promoting CSR as a way of upholding joint value creation and sustainable relationships between the company and its stakeholders. A common denominator for the more recent approaches to corporate 
responsibility is that economic responsibility is only one out of numerous functions incorporated in the notion of CSR. It is agreed that the fulfillment of economic responsibilities and profit are a necessity for all other corporate functions; hence, a necessary precondition for CSR. The following approaches to CSR are in contrast to the economic view, promoting CSR engagements as something positive for business.

Freeman (2010), the originator of the stakeholder theory, suggests that business and ethics cannot be separated, as the main objective of CSR is to carry out responsibilities and generate value to stakeholder groups. Hence, the stakeholder approach to CSR views the corporation as a network of stakeholders implying that CSR is all about stakeholder management. Freeman's initial definition of a stakeholder is "any group or individual who can affect or is affected by the organization's objectives" (Clifton \& Amran, 2011). Compared to most theories of strategic management, that often encompass underlying moral messages, stakeholder theory articulates explicit ethical arguments as a principal element of managing organizations. Hence, stakeholder theory critically studies not only the goals of corporate activity but also the ways of getting there by addressing morals and values. (Philips et al., 2003) Consequently, stakeholder theory argues that studying how the company deals with the stakeholder's interests is a good assessment of a company's corporate social performance. In other words, managing according to the stakeholder principle, creating value for stakeholders and fulfilling responsibilities to these groups, is what achieving social responsibilities is all about. (Clifton \& Amran, 2011).

One of the most utilized definitions of CSR over time is Carroll's (1999) four-part definition of CSR, often referred to as the pyramid of CSR, in which the author defines CSR as the total expectations that society has of organizations at a given point in time. The total social responsibility of firms include economic, legal, ethical and philanthropic duties and the pyramid shape illustrates how these functions must be fulfilled one by one to 'move up' to the next level. Carroll (1999) states that the economic and legal responsibilities are basic tasks that are required of business by society. The ethical responsibilities can be described as an obligation to do what is expected of societal and ethical norms, while philanthropic responsibilities refer to the extra activities companies perform apart from fulfilling the ethical expectations. Furthermore, Carroll's approach to CSR is in tune with the stakeholder view as each of the four areas of responsibility in the pyramid addresses the needs of different stakeholders and when simultaneously dealt with, generates value to both business and society. (Caroll, 1999). Carroll (2016) revisited his definition of CSR and concluded there are Four strong drivers of CSR taking hold in the 1990s and continuing forward have solidified its primacy. These include globalization, institutionalization, reconciliation with profitability, and academic proliferation (Carroll 2016).

The fact that CSR can create shared value to business and society simultaneously is further emphasized by the well-known economist Porter and Kramer (2006). These authors highlight the reinforcing relationship between strategy and society by linking CSR with a firm's competitive advantage. Porter and Kramer argue for two types of CSR engagement; responsive and strategic CSR, where the first is concerned with being a good corporate citizen by migrating harm from the corporate value chain and the latter refers to using CSR to gain a unique position on the market and thereby attain strategic benefits from CSR. (Porter \& Kramer, 2006). 


\section{Communicating CSR - Brand Management}

While establishing CSR efforts by the companies in Malaysia are rapidly receiving recognition through awareness of social reporting awards like the annual MESRA (Malaysian Environmental and Social Reporting Award), these companies are also pinning on this platform to continue to sustain the image and corporate reputation of the company. The company can create a brand perspective by the solid foundation of a CSR effort or program.

In previous researches, many attempts have been made to look at the perceptions of the public on the issue of CSR. Tan and Komaran (2006) researched the perceptions of the public on CSR upon Singaporean companies following the Carroll's and Lawrence CSR frameworks. The discussion is detailed on how CSR engagements could help the companies increase sales and market share while strengthening brand positioning and improving the corporate reputation as a whole.

Ideally, what is communicated in terms of principles and actions differ, the platform for creating a brand territory is limited. The communication platform can be affected by, for example, corporate documents, actions, and media perceptions. Branding represents a cornerstone in the corporate marketing umbrella. It is a simplifying symbol that helps stakeholders distinguish between sales efforts. Values such as CSR are intangible; the brand thus becomes a guarantee for the communicated social values.

With so much emphasis given towards to public listed companies (PLCs) in Malaysia to drive CSR efforts, there are many approaches taken by the government to make sure that the companies perform at their best for example by implementing Key Performing Index (KPI) in 2004. The introduction of 'Silver Book' with guidelines to assist PLCs in clarifying and quantifying their social obligations was a pioneering move by the Government through the Transformation Manual which was initiatives identified for their importance for change and potential impact on value to nation-building.

Companies were encouraged to participate, and nearly a decade after the implementation, the CSR efforts which have evolved are now branded through the imagery of each company. Through this research, it hopes to identify and explore how CSR efforts have created a brand of its own through the participation of sustainability over the years.

\section{Integrating CSR and Brand Management}

CSR can provide companies with a new source of differentiation and strength for the brand. Additional benefits of CSR for companies are new market opportunities, protection of reputation, increase in the level of customer liking and brand loyalty, attracting investment and avoiding risks concerning future restrictive legislation (Williams, 2008) From what has been found in the reading of literature, CSR and brand management are generally and for the most part reviewed as two separate areas of study. A few authors have raised the concern as the theme of the lack of connection between CSR and brand management. Furthermore, Werther and Chandler (2005) argue for strategic CSR as insurance for global brands, saying that a CSR mindset incorporated in the brand strengthens the brand-user bond and reduces the brand's vulnerability to internal management failures. Bhattacharya et al. (2007) examine the influence of the extent to which a company's social activities are integrated into the brand's competitive positioning on consumer attitudes to CSR. They argue that brand's that base it's positioning on CSR, integrating CSR strategy in core business strategy is more likely to reach CSR-specific 
benefits from consumers than brands that solely engage in CSR without positioning the brand accordingly. Moreover, the study made by Melo and Galan (2011) confirms CSR as a valid source of intangible competitive advantage by analyzing the impact of CSR on brand value. Their study also emphasizes the importance of connecting CSR with corporate strategy by saying that without alignment between the two, CSR is not used to its full potential and the positive impact from CSR on brand value will be lesser. This existing literature that brings together CSR and brand management is for the most part concerned with establishing and highlighting the positive and reinforcing relationship between CSR and brand management. It can be agreed that CSR and branding has a lot to gain from being combined but how should such an integration go about; how can companies turn these new insights into action?

After studying the development and conceptualization of CSR and brand management, it is determined that the concept of strategic CSR in combination with the cultural and identity approach to brand management would form a relevant base for the analysis of the research and answering of the research question.

Consequently, this study takes a new perspective that guides companies in how to integrate the notion of strategic CSR in the corporate brand to build a competitive advantage. Hence, the study serves to complement and develop the existing theory on strategic CSR by taking a brand management perspective: adding integration of strategic CSR in the corporate brand to the process of developing a strategic CSR engagement.

\section{Public-Listed Companies in Malaysia}

In Malaysia, the most common type of limited companies is those limited by shares. These companies are incorporated and governed by the Companies Act, 1965. Companies limited by shares will carry "Bhd," "Berhad" behind their names according to Section 22(4) of the Act. According to Bursa Malaysia (2018), there are 806 companies listed on Bursa Malaysia. In this study, two companies in the telecommunication sector were chosen which are Maxis Berhad and Axiata group. Maxis Berhad is the largest telecom operator in Malaysia with $38.1 \%$ market share, followed by Celcom which represent Axiata group with $33.7 \%$ market share (Macropolis, 2015).

\section{Maxis Berhad}

At Maxis, the commitment towards responsible practices is embedded into CSR strategy: developing and enriching lives, creating a great place to work and advocating environmentally friendly practices. This is underpinned by Maxis's commitment to upholding the highest standards of governance as outlined in the Malaysian Code of Corporate Governance.

As the leading communications service provider in Malaysia, Maxis enables both individuals and businesses to connect and communicate anytime and anywhere. The company's passion drives them to innovate and market services that are worry-free for our customers, so they can stay focused on the pursuit of their goals. Maxis cater to their enterprise customer; their integrated solutions are a compelling proposition which enables them to enhance their business goals. Maxis mission is "Our people are our competitive advantage" therefore, they prepare for the future today by developing the skills and talent of all employees, making Maxis a great place to work for great people (Maxis Berhad, 2018) Underpinning this is the Maxis Way, Maxis approach to work that 
champions passion, positivity, and collaboration. Beyond connecting people with their services, Maxis are passionate about making a positive impact on the community in which they operate. Maxis's Corporate Social Responsibility efforts aim to develop and enrich the community, customer, and partners, creating a fun place to work and advocating environmentally friendly practices (Maxis Berhad Sustainability Report, 2014).

Maxis Berhad is focusing on becoming an operator of choice by providing the best network, delivering unmatched customer experience, making a difference to the community and adopting good practices in procurement. Maxis also focus on creating a great place to work through implementing culture change and a new way of working, providing training and development, ensuring health and safety, and striving for the benefits and rights....... I am advocating environmentally friendly practices by increasing resources efficiency, proper carbon and waste management.

\begin{tabular}{|c|c|c|}
\hline & Focus & Approsch \\
\hline \multirow{4}{*}{$\begin{array}{l}\text { Becoming an } \\
\text { Operator of Choice }\end{array}$} & Best Network & $\begin{array}{l}\text { - Best Network initiative to support customer needs and } \\
\text { requirements }\end{array}$ \\
\hline & $\begin{array}{l}\text { Delivering on Unmatched } \\
\text { Customer Experience }\end{array}$ & $\begin{array}{l}\text { - Worry-free Internet access } \\
\text { - Supporting SMEs } \\
\text { - Improving customer experience journey } \\
\text { - Responding to queries and resolving complaints } \\
\text { - Investing in our service capabilities } \\
\text { - Engaging with stakcholders for customers feedback }\end{array}$ \\
\hline & $\begin{array}{l}\text { Making o Difference to the } \\
\text { Community }\end{array}$ & $\begin{array}{l}\text { - Empowering the comenunity through technology and } \\
\text { - education } \\
\text { - Providing access to underserved communities } \\
\text { - Relief aid for flood victims } \\
\text { - Nurturing future talent }\end{array}$ \\
\hline & Good Practices in Procurement & $\begin{array}{l}\text { - Advocating green practices among our vendors } \\
\text { - Ensuring ethical practices and transparency in procurement }\end{array}$ \\
\hline \multirow{4}{*}{$\begin{array}{l}\text { Creating a Great } \\
\text { Place to Work }\end{array}$} & $\begin{array}{l}\text { Culture Change and } \\
\text { New Way of Working }\end{array}$ & $\begin{array}{l}\text { - Living the Maxis Way } \\
\text { - New ways of working } \\
\text { - Employee engagement }\end{array}$ \\
\hline & Training and Development & $\begin{array}{l}\text { - Maxis Management Associate Programme } \\
\text { - Maxis Internship Programme } \\
\text { - Engaging young talent }\end{array}$ \\
\hline & Ensuring Health and Sofety & $\begin{array}{l}\text { - Health and Safety management } \\
\text { - Safe working culture initiative }\end{array}$ \\
\hline & Benefits and Rights & $\begin{array}{l}\text { - New benefit programme to support the new culture } \\
\text { - Ethics, anti-corruption and tribery }\end{array}$ \\
\hline \multirow{3}{*}{$\begin{array}{l}\text { Advocating } \\
\text { Environmentally } \\
\text { Friendly } \\
\text { Practices }\end{array}$} & Resource Elticiency & - Increasing energy efficiency of network faciltaies \\
\hline & Carbon Management & - Reducing $\mathrm{CO}_{2}$ footprint \\
\hline & Waste Management & - Supporting green practices in the office \\
\hline
\end{tabular}

Table 1. Maxis CSR focus area (Maxis Berhad Sustainability Report 2014)

\section{Axiata Group}

Axiata Group Berhad (Axiata group) is one of the largest Asian telecommunications groups in Asia with over 260 million customers. Axiata group's vision is to be a regional champion by 2015 by piecing together the best throughout the region in connectivity, technology, and talent, uniting them towards a single goal: Advancing Asia.

Axiata group has controlling interests in mobile operators in Malaysia, Indonesia, Sri Lanka, Bangladesh, and Cambodia with significant strategic stakes in India and 
Singapore. Also, the Malaysian grown holding company has a stake in non-mobile telecommunications operations in Pakistan.

The Group's mobile subsidiaries and associates operate under the brand name "Celcom" in Malaysia, "XL" in Indonesia, "Dialog" in Sri Lanka, "Robi" in Bangladesh, "Smart" in Cambodia, "Idea" in India and "M1" in Singapore. Added to this, the Group has established communications infrastructure solutions and services company called "edotco."

The Group revenue for 2016 was RM21.6 billion (USD 5.2 billion). It's market capitalization stood at over RM42.3 billion (USD 9.4 billion) at the end of 2014 . The Group employs over 25,000 people across Asia.

Axiata group is committed to the triple bottom line of economic, environmental and social management - in line with the broader goal of Advancing Asia. The approach to sustainability is based on the four main pillars of Beyond Short Term Profits, Nurturing People, Process Excellence, and Planet and Society. Figure 1 shows the details of four main pillars in Axiata group's sustainability approach.
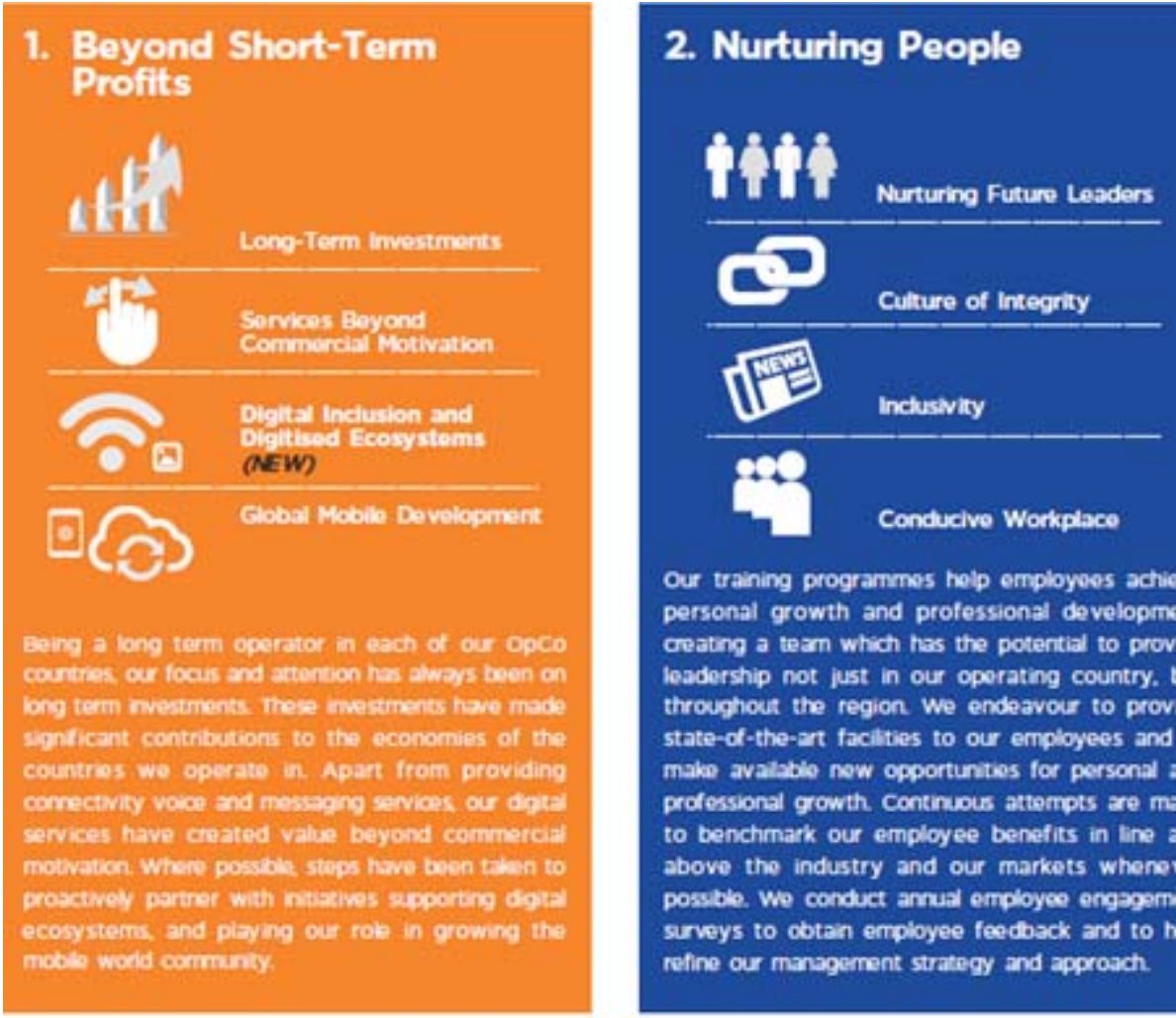

Our training programmes help employees achiove personal growth and professional development ceating a team which hes the poteritial to provide leadership not just in our operating country, but throughout the region we endeavour to provide state-of-the-art facilties to our employees and to make avalable now opportunities for personal and professional growth conthuous attompts are made to benchmark our employee benefits in line and above the industry and our markets whenever possible. We conduct annal employee engaganent surveys to obtan employee feedoack and to help refine our managerment strategy and approach. 

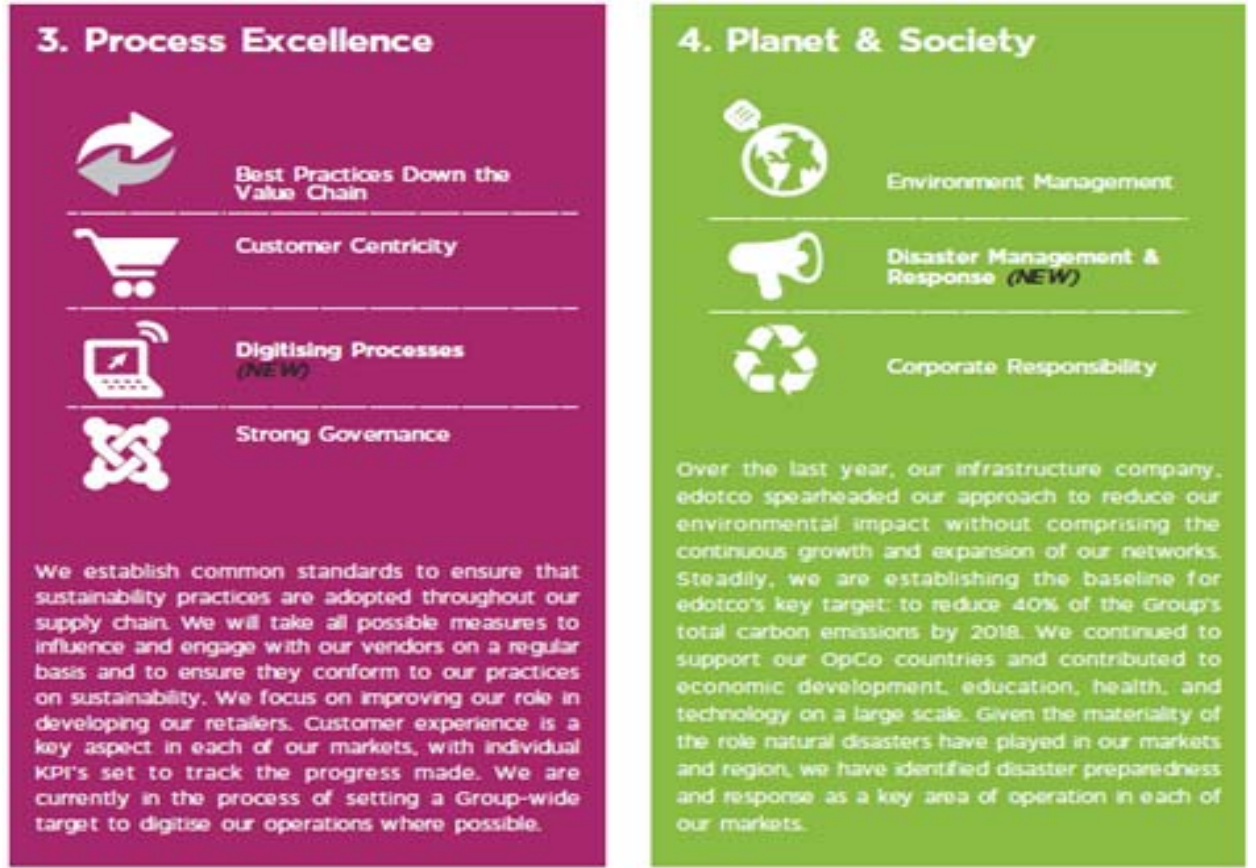

Figure 1. The four pillars of sustainability at Axiata Group (Axiata Group Sustainability Report 2013)

\section{Methodology}

This research is conducted using a qualitative approach through a semi-structured indepth interview. According to Seidman (2006), the purpose of in-depth interviewing is not to get answers to questions, nor to test hypotheses, and not to evaluate as the term is normally used, but the root of in-depth interviewing is an interest in understanding the lived experience of other people and the meaning they make of that experience. A total of six head of departments and senior officers who are representing MAXIS Berhad and Axiata group were interviewed. The selection of the samples are determined and based on criteria, participants who have direct involvement and experience in CSR for both telecommunication companies. This selection approach is to encompass a range of decision-makers on green initiatives from the head of department and practitioners. This group of stakeholders is important in keeping the CSR initiatives closer to the company's vision and mission. All participants were asked about their responsibilities and duties in their organization and also their specific roles in handling CSR.

\section{Results and Discussion}

This study is to examine branding CSR from the perspective of a telecommunication company by its stakeholders - in the field of public relations. Specifically, the main objectives of this study are:

(i) To identify the perception of branding CSR by PLCS

(ii) To explore PLCs level of understanding on branding CSR

(iii) To examine the role of public relations practitioners in PLCs branding CSR

The results are presented and discussed based on these three objectives. 
As commonly known CSR and its effort have a direct link with corporate reputation. Social responsibilities are now seen as efforts which companies tap on to strengthen their imagery within the public's eye further. Findings indicated that both company, Maxis and Axiata group has a solid CSR framework that brands its CSR very active and reliable to its business and economy. Having a sustainable program enhances the CSR brand of a company, and it is reputable for the mother company's brand name. As such, Maxis and Axiata group have programs that were established to re-enact this objective.

The results indicate the companies' best practices are learned from one another due to both companies are from the same industry. Although there was no consensus in terms of exchanging ideas, it can be highlighted and to agree that both companies practice similar CSR pillars and execution of any activities were cross-check against a competitor to perform better or outweigh the competitor in CSR activities. As such, the branding of CSR by both companies is aligned by industry standards. This is also underpinned by the commitment of both Maxis and Axiata group to uphold the highest standards of governance as outlined in the Malaysia Code of Corporate Governance.

From this study too, both Maxis and Axiata group perceive that a strong CSR results in solid branding for CSR. The commitment showed by both company in the CSR framework portrays the seriousness of both companies to ensure CSR pillars are not just for the sack of having one but to execute them for better performance in terms of the company's branding for CSR.

\section{The Level of PLCs' Understanding on Branding CSR}

Both Maxis and Axiata group referred to branding CSR to a successful CSR programme. The brand imagery personified through the pillars is the result of constant input to its stakeholders. For Maxis, successful branding CSR is a long-standing CSR program that results in sustainable projects. Example, the Maxis Cyberkids Camp, initiated since 2002 successfully conducts education on the internet and other technological tools which to date has reached to nearly 10,000 students from 1,500 schools. Axiata group, on the other hand, highlighted its anchor community program, Axiata Group Young Talent Programme (AYTP), where Axiata group pledged RM100 million for the development of local students.

There was also the internal and external approach of understanding branding CSR as found in this study. The internal approach of which both Maxis and Axiata group lamented is that internal engagements are vital, and it is much higher. The workplace is a strong pillar highlighted by both companies. Maxis recognized dialogues between leaders and employees are important in helping people feel more engaged; this includes updating them on the latest products and services as well as the business as a whole. Another effort from Maxis was the introduction of Maxis Way to its employees, a workshop to inspire to change and embrace the company's way of business.

On another hand, the external approach to better understands branding CSR from both companies perspective has to engage relevant stakeholders. This includes shareholders, regulators, government authorities, suppliers, media and community. In the case of Axiata group, each of the mention stakeholders was engaged as below: 


\begin{tabular}{lll}
\hline Stakeholder & Types of Engagement & Frequency \\
\hline Shareholders & $\begin{array}{l}\text { Annual General Meeting Investor } \\
\text { Roadshows Meeting(s) with the } \\
\text { Top } 100 \text { Investors Analyst Meetings }\end{array}$ & Annually \\
Regulators and & $\begin{array}{l}\text { Compliance with the Malaysian } \\
\text { Government }\end{array}$ & Ongoing \\
Authorities & $\begin{array}{l}\text { Communications and Multimedia } \\
\text { Commission (MCMC)Compliance } \\
\text { with Bursa Malaysia }\end{array}$ & \\
Request for Proposals (RFP) Supplier & Code of Conduct Vendor Survey & Ongoing \\
Media & $\begin{array}{l}\text { Media Survey } \\
\text { Media Releases / Conferences }\end{array}$ & Ongoing \\
Community & $\begin{array}{l}\text { Axiata group Young Talent Programme } \\
\text { Axiata group's Sustainability Programmes }\end{array}$ & Quarterly \\
& & Ongoing \\
\hline
\end{tabular}

\section{The Role of Public Relations Practitioners in Branding CSR}

Both Maxis and Axiata group indicates that public relations practitioners are subject matter experts (SMEs) when it comes with branding CSR for both companies. Both of the department heads for corporate affairs (Maxis) and corporate communications (Axiata group) are the CSR Working Committee member and driver in their capacity. The role is highlighted to be the mechanic of CSR framework for both companies because their departments are the main driver to the function of CSR while supported by the various departments including supply chain, marketing, sales, and human resources. But due to the lack of interaction with other departments, the role of public relations lacks in terms of understanding and its structure. A cohesive integration group in developing a strategic communication strategy for branding CSR together should be considered and adopted.

Both companies also expect that public relations role should integrate and collaborate with other departments or functional groups to be more effective and strategic as outlined in the Public Relations Excellence Theory. It is highlighted that because the role and function of the departments are also examining through their annual Key Performance Index (KPI) on CSR and thus making the public relations practitioners playing a vital role in creating the solid branding CSR image for the company.

The CSR module at both Maxis and Axiata group is vital to develop a communication strategy for CSR. And public relations practitioners in both companies agree that by living and breathing to these pillars of CSR make it easier to communicate the messaging. The key pillars function as the backbone of their messaging and thus putting their role very much inclined to refer to the respective CSR framework as a guideline.

It is also discovered that the role of public relations is the facilitator, the agent tool and point of reference for CSR. With that being said, their role is not just confined to communicating messages but also as the body that connects and aligns all stakeholders involved in CSR approaches. The communication tools that these practitioners used, may it be through internal communications (newsletter, intranet, and email) or external communications (press releases, media briefings and interviews), are vital because tapping on the various channels could send the message across to a bigger audience. Figure 2 summarizes the role of public relations in branding CSR. 


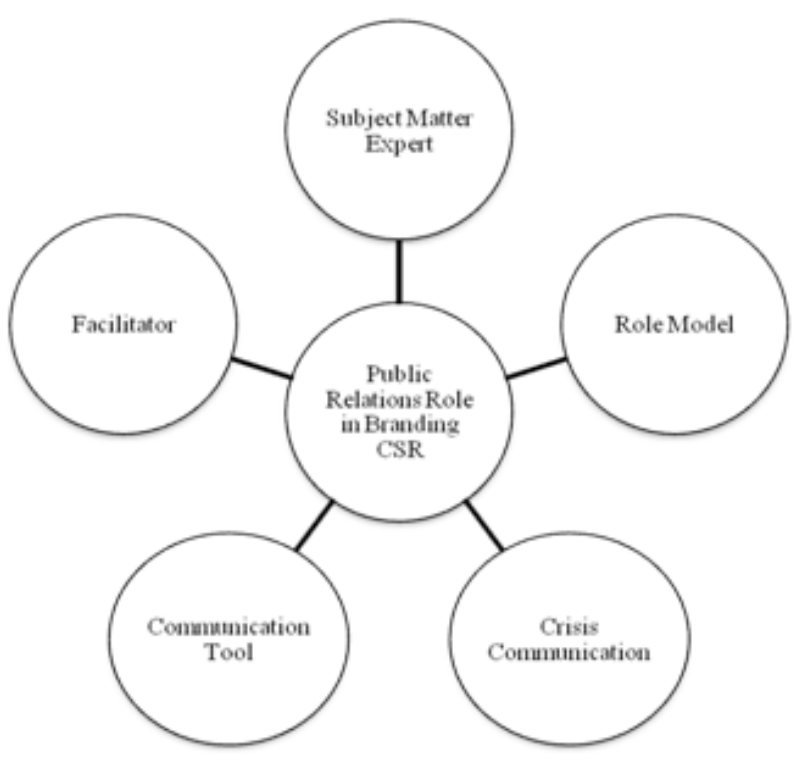

Figure 2. Public relations role in branding CSR

At Axiata group, a comprehensive communication checklist is set to ensure public relations practitioners do not miss out any platform that is relevant due to the Group's wide connection of employees across the region including Cambodia, Indonesia, Bangladesh, and Sri Lanka.

In short, the role of public relations in both companies is common, because both companies are in the same industry and less to say a competitive industry as a whole. But with rapid changes in the market place today which includes globalization, technology, global economics, competition, and social system, practitioners have to keep abreast with the growing knowledge of brand and communications.

\section{Conclusion}

Overall, this case study has provided an insight into PLCs perception towards branding CSR. It can be construed that reputation is the main variable on PLCs perception on branding CSR. The general understanding on PLCs perception on branding CSR is that reputation occurs at a higher stake when companies are more compelled to invest in sustainable programmes of which directly impacts stakeholders who are important to the company's business and economy. Both companies studied from the telecommunication industry perspective shares a similar stakeholder engagement list, and therefore it is also concluded that due to this similarity and industrial standards, both Maxis and Axiata group apply to best practices approach in pursuing a successful brand of CSR.

This study suggests that the role of public relations in both companies is common, because both companies are in the same industry and less to say a competitive industry as a whole. But with rapid changes in the market place today which includes globalization, technology, global economics, competition, and social system, practitioners have to keep abreast with the growing knowledge of brand and communications.

Funding: This research was sponsored by RCMO. Universiti Sains Malaysia. 


\section{References}

Abdul Rashid, Z, A. \& Ibrahim, S. (2010). Executive and management attitude towards corporate social responsibility in Malaysia. Corporate Governance, 2(4), 10-16.

Axiata group Group (2013). Axiata group group sustainability report. Retrieved from http:// www.Axiata group.com/investor-relations/2013/ar/ on October 26, 2017.

Azlan, A., Mustafa, M. Z., Maliah, S., Sarker, T., \& Ooi, S. K. (2013). Empowering society for better corporate social responsibility (CSR): The case of Malaysia. Kajian Malaysia, 31(1), 57.

Bursa Malaysia (2018). List of companies in Bursa Malaysia. Retrieved from http:// www.bursamalaysia.com/market/listed-companies/list-of-companies/mainmarket/ on February 5, 2018.

Carroll, A. B. (2016). Carroll's pyramid of CSR: taking another look. International journal of corporate social responsibility, 1(1), 3.

Carroll, A. B., \& Shabana, K. M. (2010). The business case for corporate social responsibility: a review of concepts, research, and practice. International Journal of Management Reviews, 12(1), 85-105.

Carroll, A.B. (1999). The pyramid of corporate social responsibility: Toward the moral management of organizational stakeholders. Business Horizons, 34, 39-48.

Clifton, D., \& Amran, A. (2011). The stakeholder approach: A sustainability perspective. Journal of Business Ethics, 98(1), 121-136.

Davis, K. (2014). The case for and against the business assumption of social responsibilities. Academy of Management Jornal, 16(2), 312-322.

Freeman, R. E., Harrison, J. S., Wicks, A. C., Parmar, B. L., \& De Colle, S. (2010). Stakeholder theory: The state of the art. Cambridge University Press.

Friedman, A. (1984). Foundations of modern analysis. Courier Corporation.

Ismail, M., Alias, S. N., \& Mohd Rasdi, R. (2015). The community as a stakeholder of the corporate social responsibility programme in Malaysia: Outcomes in community development. Social Responsibility Journal, 11(1), 109-130.

Jamilah, A., \& Suriati, S. (2017). Positioning of corporate social responsibility in media reporting. Corporate Behavior and Sustainability: Doing Well by Being Good, 121-137.

Macropolis (2015). Malaysia's largest telecoms. Retrieved from http://www.marcopolis.net/ top-telecoms-in-malaysia-malaysia-s-largest-telecoms.htm on January 29, 2018.

Matten, D. \& Crane, A. (2005). Corporate citizenship: Towards an extended theoretical conceptualization, Academy of Management Review, 30, 166-179.

Maxis Berhad (2018). Shaping a sustainable future. Retrieved from https:// www.maxis.com.my/en/about-maxis/corporate-responsibility/sustainabilityreports.html on January, 30, 2018.

Maxis Berhad (2014). Maxis berhad sustainability report. Retrieved from http://maxis.my/ ar2014/images/download/pdf/maxis_ar2014.pdf on October 26, 2015.

Melo, T., \& Galan, J. I. (2011). Effects of corporate social responsibility on brand value. Journal of Brand Management, 18(6), 423-437.

Porter, M. E., \& Kramer, M. R. (2006). The link between competitive advantage and corporate social responsibility. Harvard Business Review, 84(12), 78-92.

Phillips, R., Freeman, R. E., \& Wicks, A. C. (2003). What stakeholder theory is not. Business Ethics Quarterly, 13(4), 479-502. 
Richardson, A. J., Welker, M., \& Hutchinson, I. R. (1999). Managing capital market reactions to corporate social responsibility. International Journal of Management Reviews, 1(1), 17-43.

Smith, N. C., Read, D., \& López-Rodríguez, S. (2010). Consumer perceptions of corporate social responsibility: The CSR halo effect.

Tan, Y. W., \& Komaran, R. V. (2006). Perceptions of corporate social responsibility: An empirical study in Singapore, Strategic Management Policy.

Werther, W. B., \& Chandler, D. (2005). Strategic corporate social responsibility as global brand insurance. Business Horizons, 48(4), 317-324.

Williams, E. (2008). CSR Europe's Sustainable Marketing Guide. BT Group and CSR Europe.

Jamilah Ahmad (Ph.D., Deakin University, Melbourne, Australia 2005) is a Professor at School of Communication, Universiti Sains Malaysia. Dr. Ahmad's research interests include environmental communication, public relations, corporate social responsibility, communication and media studies, e-learning, and new media technology. 